\title{
Management of Post-Throidectomy Voice Problems: Surgeon's Perspectives
}

\author{
Seung Won Lee \\ Department of Otolaryngology-Head and Neck Surgery, Bucheon Hospital, Soonchunhyang University College of Medicine, \\ Bucheon, Korea
}

\section{갑상선 수술과 관련된 음성장애의 치료-수술적 관점}

\author{
이 승 원 \\ 순천향대학교 의과대학 부천병원 이비인후과학교실
}

\author{
Received July 31, 2015 \\ Revised August 29, 2015 \\ Accepted September 10, 2015 \\ Address for correspondence \\ Seung Won Lee, MD, PhD \\ Department of Otolaryngology- \\ Head and Neck Surgery, \\ Bucheon Hospital, \\ Soonchunhyang University \\ College of Medicine, \\ 170 Jomaru-ro, Wonmi-gu, \\ Bucheon 14584, Korea \\ Tel +82-32-621-5450 \\ Fax +82-32-621-5016 \\ E-mail1sw0922@schmc.ac.kr
}

Recurrent laryngeal nerve (RLN) injury is not the only cause of voice alteration after thyroidectomy; many patients noticed slight voice changes after thyroidectomy, without evidence of RLN injury. Typical symptoms are easy fatigue during phonation and difficulty with high-pitched and singing voices; other symptoms are paresthesia, vague voice changes, throat discomfort, swallowing difficulties, and the feeling of choking. This collection of symptoms appears to be a real syndrome, which we have named post-thyroidectomy syndrome. In the management of these patients with unilateral vocal cord paralysis, injection laryngoplasty techniques have regained popularity in recent years. Because it is easier and less invasive than conventional medialization thyroplasty and may provide equally durable and effective results. As a novel voice rehabilitation procedure, RLN reinnervation has advantages which prevent the progressive loss of thyroarytenoid muscle tone, tension and potential of restoring a normal voice with preserving of laryngeal anatomy. In this manuscript, we could get a lots of useful information how to manage thyroidectomy related vocal fold paralysis with adequate different techniques at different situations.

Korean J Otorhinolaryngol-Head Neck Surg 2016;59(1):1-8

\section{서 론}

갑상선 수술의 급격한 증가로 인해 갑상선 수술 후 음성장 애 또한 급격하게 증가하고 있다. 수술 중 반회후두신경을 보 존한 경우에도 대부분의 환자들이 술 후 고음장애 및 경부 불편감과 같은 다양한 증세를 호소한다. 저자는 이를 갑상선 수술 후 증후군(post-thyroidectomy syndrome, PTS)으로 명 명하였다. 갑상선 수술과 관련된 성대마비는 환자와 술자 모두 를 당황하게 하는 합병증이다. 현재의 표준 치료인 내전 갑상성 형술 \pm 피열연골내전술(medialization thyroplasty \pm arytenoid adduction)은 경부 절개가 필요하여, 심리적, 육체적인 부담이 된다. 이에 비하여 성대주입술은 비침습적이며 합병증이 상대 적으로 적고, 입원이나 전신마취의 필요가 없는 장점이 있어
서, 기존 치료의 많은 부분을 대체하고 있다.

또한 기존의 표준 치료인 갑상성형술은 시간이 지나면서 신 경 지배 손상에 따른 성대 근육의 위축(denervation atrophy) 으로 인하여 치료 효과가 떨어지거나 재수술을 요하는 단점 이 있다. 이에 비하여 반회후두신경 신경재지배술[recurrent laryngeal nerve(RLN) reinnervation]은 성대 근육량(volume) 및 긴장도(tone)를 유지하여 생리적이고 장기적인 음성 호전이 가능한 장점이 있다.

본 논문에서 저자는 갑상성형술 \pm 피열연골내전술(thyroplasty with arytenoid adduction), 성대주입술(injection laryngoplasty), 반회후두신경 신경재지배술 등의 수술방법, 장 단점, 임상 데이터를 소개하고자 한다. 


\section{본 론}

\section{갑상선 수술 후 증후군(PTS)}

반회후두신경과 상후두신경과 같은 신경이 손상받지 않는 단순 갑상선 수술 후에도 대부분의 환자들은 술 후 경부 불편 감, 감각장애, 고음장애(high pitched voice), 노래장애(singing difficulty)와 같은 다양한 음성장애를 호소한다.

이들 증세의 모음은 마치 증후군(syndrome)과 같은 양상을 보여, Park 등')은 2008년 이를 "갑상선 수술 후 증후군(postthyroidectomy syndrome)"이라고 명명하였다. 갑상선 수술 후 증후군의 원인으로는, 후두기관 고착(laryngotracheal fixation), 상후두신경 손상(direct injury of superior laryngeal nerve), 림프 부종(laryngeal lymph edema), 피대근 기능손상 (strap muscle) 등이 원인으로 추정되고 있으며, 이 중 후두기 관 고착이 가장 중요한 원인으로 추정된다(Fig. 1).

저자의 갑상선 수술 후 증후군 환자들의 장기추적 결과 상 후두신경의 손상이 발생하지 않는 경우, 고음장애, 노래장애 와 같은 증세들은 술 후 1 2년이 지나면서 대부분 호전되는 소견을 보였다.

갑상선 수술 후 증후군을 예방하기 위한 현실적인 방법으로 정확한 박리면(dissection plane)을 따라 수술을 진행하여, 수 술 후 유착을 최소화하고, 불필요한 피대근(strap muscle)의 절단을 피하는 것이 필요하다.") 수술 후 후두기관 고착(laryngotracheal fixation)을 감소시키기 위하여 유착이 발생하기 전인 술 후 2주째부터 경부 신전운동(head \& neck stretching exercise)을 통하여 증세를 호전시킬 수 있다.5)

\section{일측 성대마비의 치료(Management of unilateral vocal fold paralysis)}

\section{관 찰}

과거에는 갑상선 수술 후 성대마비가 발생한 경우, 수술 중 에 반회후두신경 절단이 확인되는 경우가 아니면, 술 후 6 12 개월까지의 성대 기능의 자연 회복을 기다렸다가, 이후에 갑 상성형술을 시행하는 것이 원칙이었다.

최근에는 6 12개월의 기간 동안 환자가 받을 정신적, 사회 적 고통을 고려하여 적극적 초기 치료가 선호되고 있다. 특 히 직업적으로 음성을 사용하거나, 성대마비에 의한 흡인성 폐렴이 발생하는 경우에는 조기 치료가 추천된다.

무엇보다도 조기 성대주입술이 성대 기능 회복에 도움을 주 는 것으로 알려져서, 적극적인 조기 치료를 시행하는 것이 최 근에는 주류 의견으로 자리를 잡은 상태이다.)

저자의 경우, 갑상선 수술 후 경부 림프부종(lymphedema)

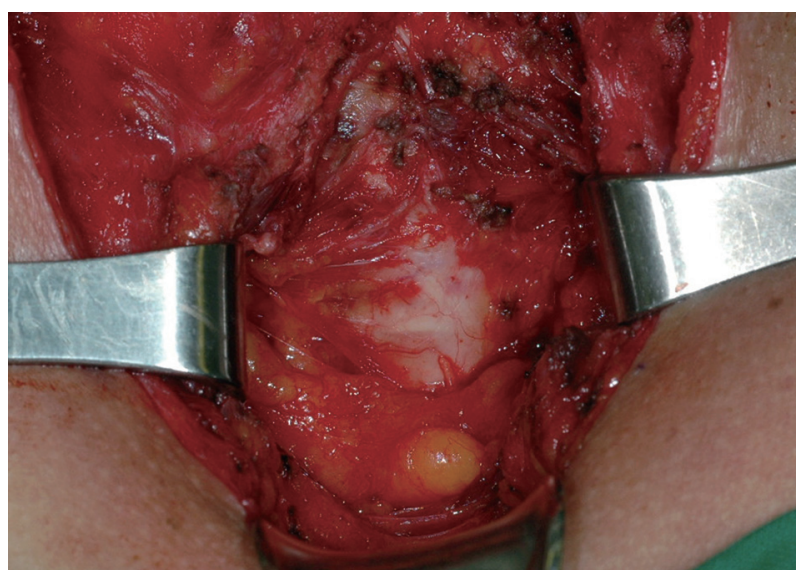

Fig. 1. Surgical photograph demonstrated severe adhesion between strap muscle and trachea at revisional thyroid surgery.

과, 기관 삽관에 의한 성대 부종이 빠지기를 기다려 술 후 1 개월 째 국소마취하에 성대주입술을 시행하는 것을 선호하고 있다.

수술 중 일측성 성대마비의 치료(Simultaneous intraoperative thyroplasty or injection laryngoplasty) 수술 중 반회후두신경을 절단하거나(iatrogenic injury) 혹 은 갑상선 암의 침범으로 인한 신경 절단의 경우에, 수술 중 즉시 성대주입술 혹은 갑상성형술을 시행할 수 있다. 장점으 로는 환자가 수술 후 본인의 반회후두신경 손상을 모르고 지나갈 수도 있고, 추가적인 시술을 시행하지 않아도 되는 점 이다. 하지만 시술 중 환자의 음성을 듣고 술식의 정도를 정하 는 미세조절(microtuning)이 불가능하고, 수술 중 반대측 반 회후두신경에도 추가적으로 손상을 줄 경우에는 수술 후 호 흡곤란을 일으킬 수 있어서, 대부분의 음성전문의(laryngologist)는 이 방법을 선호하지 않는다.

\section{갑상성형술(Thyroplasty) \pm 피열연골내전술(arytenoid} adduction)

갑상선 수술 후 일측성 영구 성대마비의 표준 치료(gold standard)는 갑상성형술 \pm 피열연골내전술이다. 1975년 Isshiki 등ㄱ 이 갑상성형술을 개발한 이후 가장 많은 임상 결과가 보고되 었고, 안정적인 치료 결과를 얻을 수 있는 장점이 있다. 하지만 시술 시 신경손상이 영구적인지 불확실한 경우 6 12개월을 기 다렸다가 시술을 해야 하며, 추가적인 경부 절개와 동위원소 치료를 받은 환자의 경우, 수술과정에서 박리(dissection)가 어 려운 단점이 있다.

일반적으로 후성문틈(posterior glottic gap)이 크거나, 마 비된 성대위치가 정상 측보다 높은 경우(vertical level differences)에는 피열연골내전술을 동시에 시행하는 것이 추천된 다. ${ }^{8)}$ 하지만 현재는 적응증의 상당부분이 성대주입술로 대체 

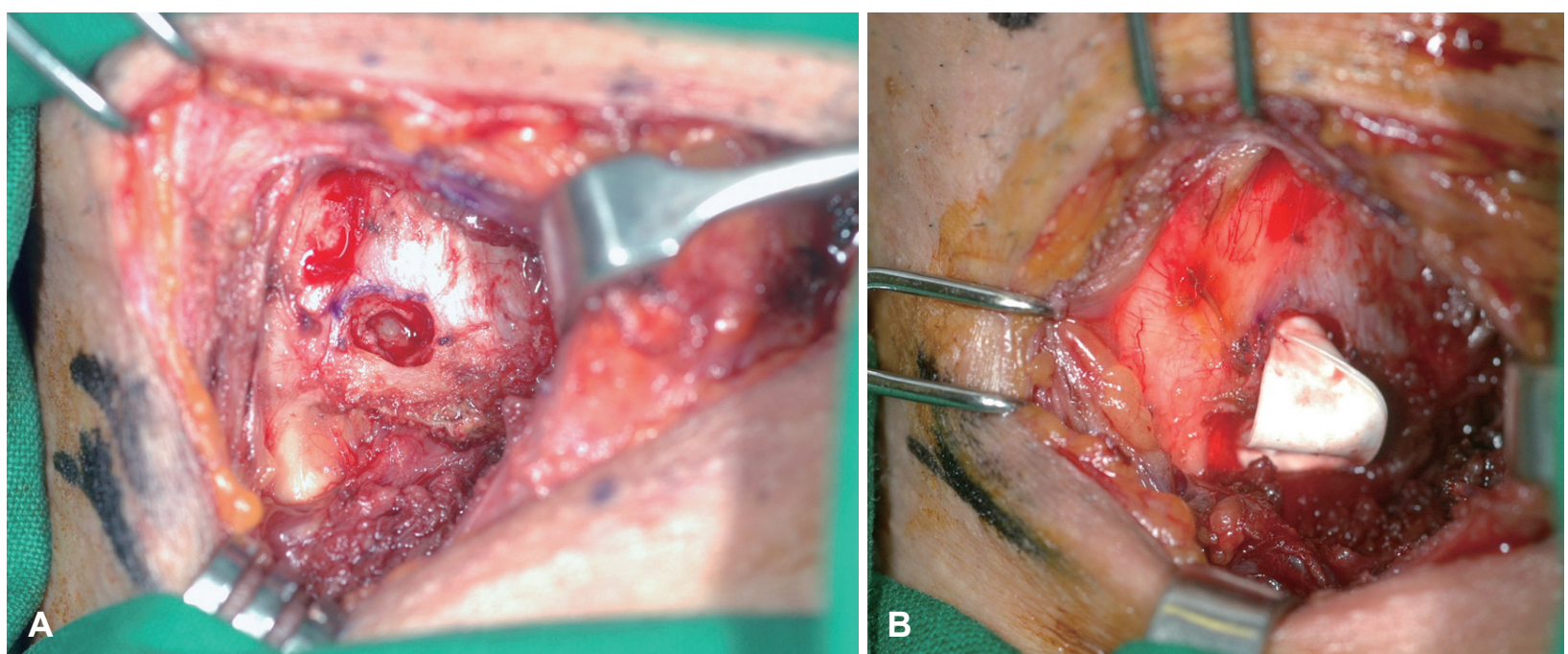

Fig. 2. Surgical photograph of Gore-Tex (polytetrafluoroethylene) thyroplasty. Surgical window was made at thyroid cartilage mid-level (A) and after Gore-Tex implanted through the window (B).
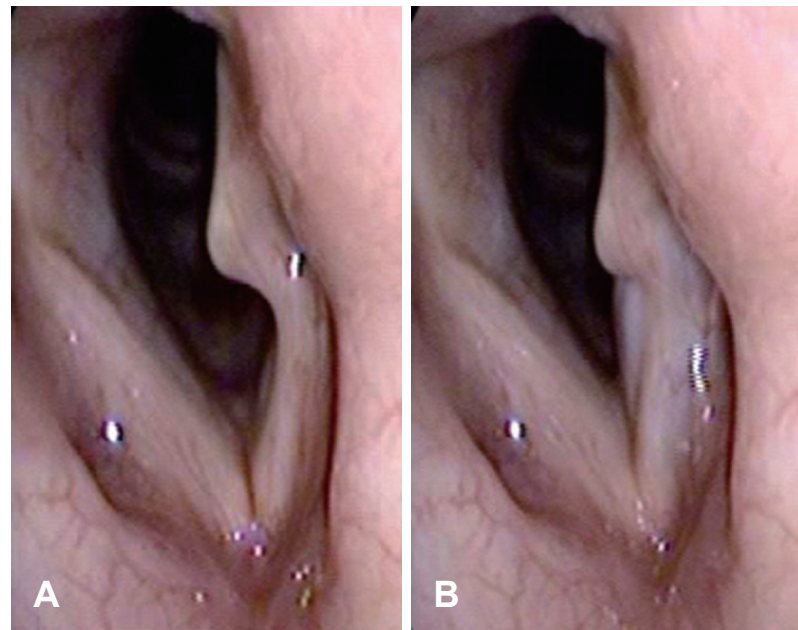

Fig. 3. Fiberscopic images of left vocal fold paralysis patients, before (A) and after injection laryngoplasty (B).

된 상태이며, 일반적으로는 발성 시 후성문틈의 간격이 $1 \mathrm{~mm}$ 이내인 경도 후성문틈(mild glottic gap)의 경우에는 성대주 입술이, 2 3 mm 이상인 중등도 이상의 후성문틈(moderate to severe glottic gap)의 경우에는 갑상성형술이 추천되고 있 다(Fig. 2). ${ }^{6}$

\section{성대주입술(Injection laryngoplasty)}

성대주입술의 장점으로는 시술이 간단하며, 입원이나 전신 마취가 필요 없어 환자에게 큰 부담을 주지 않고 음성 호전과 음성과 관련된 삶의 질 향상이 가능하다는 점이다. 이는 특히 말기 암에 의한 성대마비, 전신마취가 어려운 고령 환자와 더 불어 갑상선절제술 등의 수술 후 발생한 성대마비 환자에게 유용하다. ${ }^{9}$

시술은 $4 \%$ 리도케인(lidocaine)으로 비강 및 후두를 마취
시킨 후 굴곡형 후두내시경으로 성대를 직접 관찰하면서 25 게이지(gauge) 주사바늘(long disposable needle)을 이용하 여 윤상갑상막을 통하거나(cricothyroid approach), 갑상연 골을 딿거나(transcartilaginous approach), 혹은 갑상설골 막을 통하여(thyrohyoid approach) 성대근(vocalis muscle) 내에 성대주입물을 주입한다(Fig. 3).

갑상선 수술과 연관된 일측성 성대마비 환자에서 성대주입 술이 특히 유용한 이유는 갑상선-두경부외과의가 직접 수술 하고 발생한 성대마비 환자에게 추가적 경부절개가 필요한 갑상성형술보다 부담이 덜하기 때문이다.

2010년 Lee 등9은 갑상선 수술 후 발생한 일시적, 영구적 성대마비 환자 34명에게 성대주입술 후 음성, 그리고 음성과 관련된 삶의 질이 호전됨을 최초로 보고하였다. 또한 장기 추 적관찰 결과 성대주입술 후 3 년까지 그 효과가 유지됨을 확 인하였다.

\section{성대주입물질의 선택}

현재 대부분의 성대주입물질은 주름살 치료를 위한 미용 성형 목적으로 개발된 조직 충전물질(space filler)의 허가 외 사항(off label)으로 성대에 사용하고 있는 것이 현실이다. 미 국 및 한국 $\mathrm{FDA}$ 승인을 받아 성대에 적용 가능한 유일한 물 질은 Radiesse ${ }^{\circledR}$ (Merz Pharma GmbH \& Co., Frankfurt, Germany)이다. 그 외에도 Aquamid ${ }^{\circledR}$ (polyacrylamide hydrogel; Ferrosan A/S, Soeborg, Denmark), ArteFill ${ }^{\circledR}$ (Artes Medical, Inc., San Diego, CA, USA), hyaluronic acid derivative(Rofilan; Rofil Medical International, Breda, the Netherland) ${ }^{10)}$ 등의 성대주입물질들이 술자의 선호도에 따라 사용 되고 있다. ${ }^{11}$ 
2015년 Moon 등 ${ }^{12}$ 은 토끼 성대마비모델에 calcium hydroxyapatite, polyacrylamide hydrogel, hyaluronic acid derivative 를 이용한 6개월간의 성대주입물질 안정성 검증실험을 한 결과, 기존의 성대주입물질들은 phosphate-buffered saline(PBS) 과 비교했을 때 경도-중등도(mild to moderate) 이물반응(foreign body reaction)을 유발하였으나, 이물육아종(foreign body granuloma)과 같은 심각한 부작용은 보이지 않았다. 따라서 현재 상업적으로 이용 가능한 성대주입물질은 큰 부작용 없이 성대에 사용할 수 있을 것으로 생각된다. ${ }^{12)}$

\section{반회후두신경 신경재지배술(RLN reinnervation)}

갑상성형술 \pm 피열연골내전술은 정태적 수술(static procedure)로서 시술 후 오랜 시간이 지나면, 탈신경지배 성대 근육 위축(denervation muscle atrophy)에 의해 음성이 악화되는 소견이 발생하여 재수술(revisional surgery)이 필요한 경우 가 많다.) 이에 반하여 반회후두신경 신경재지배술(RLN reinnervation)은 성대 근육량(volume) 및 긴장도(tone)를 유지하 여 생리적이면서도 장기적인 음성 호전이 가능한 장점이 있 다. ${ }^{13)}$ 하지만 신경재생이 일어나기 위해서 상당한 시간이 걸리 기 때문에 보통 음성 호전을 환자가 느끼기에는 3 6개월간의 기간이 필요하다는 단점이 있다. ${ }^{14)}$

2014년 Lee 등든 은 19명의 일측성 영구 갑상선 성대마비 환 자를 대상으로 수술 중 반회후두신경 신경재지배술(intraoperative simultaneous RLN reinnervation) 후 주관적, 객관적
음성지표가 수술 후 2년째까지 유의하게 호전됨을 전향적으로 보고하였다.

직접 반회후두신경 신경재지배술(direct reinnervation)은 절 단된 신경이 긴장 없이(tension free) 접합이 가능한 경우, 9-0 나일론(nylon)을 사용하여 4 5회의 신경외막 봉합술(epineural suture)을 시행하게 된다(Fig. 4). 하지만 절단 후 결손부 위가 커서 긴장 없는 접합이 불가능한 경우에는 피대근(strap muscle)으로 가는 목신경고리(ansa cervicalis)와 절단된 반 회후두신경을 접합시킨다(ansa-RLN reinnervation)(Fig. 5).

\section{양측성 성대마비의 치료(Management of bilateral vocal fold paralysis)}

양측성 성대마비는 갑상선 수술 후 발생하는 가장 심각한 합병증으로 약 $1 \%$ 정도에서 발생하는 것으로 알려져 있다. ${ }^{16)}$ 양측성 성대마비가 발생한 경우 마비된 성대의 위치에 따라 임 상적으로 내전형(adductor type), 외전형(abductor type)으로 분류할 수 있다.

내전형 양측성 성대마비의 경우, 수술 후 즉각적인 호흡곤 란을 호소하는 경우가 있어서, 환자와 의사 모두 당황하는 경 우가 많다. 이에 반하여 외전형 양측성 성대마비의 경우, 수술 직후에 호흡곤란과 같은 응급 상황이 없으나, 지속적으로 열 려 있는 성대로 인하여 환자는 연하 시 흡인(aspiration), 기식 음(breathy voice)과 같은 음성장애로 고통을 받게 된다(Fig. 6). 치료방법으로는 흡인을 호전시키는 연하훈련(swallowing
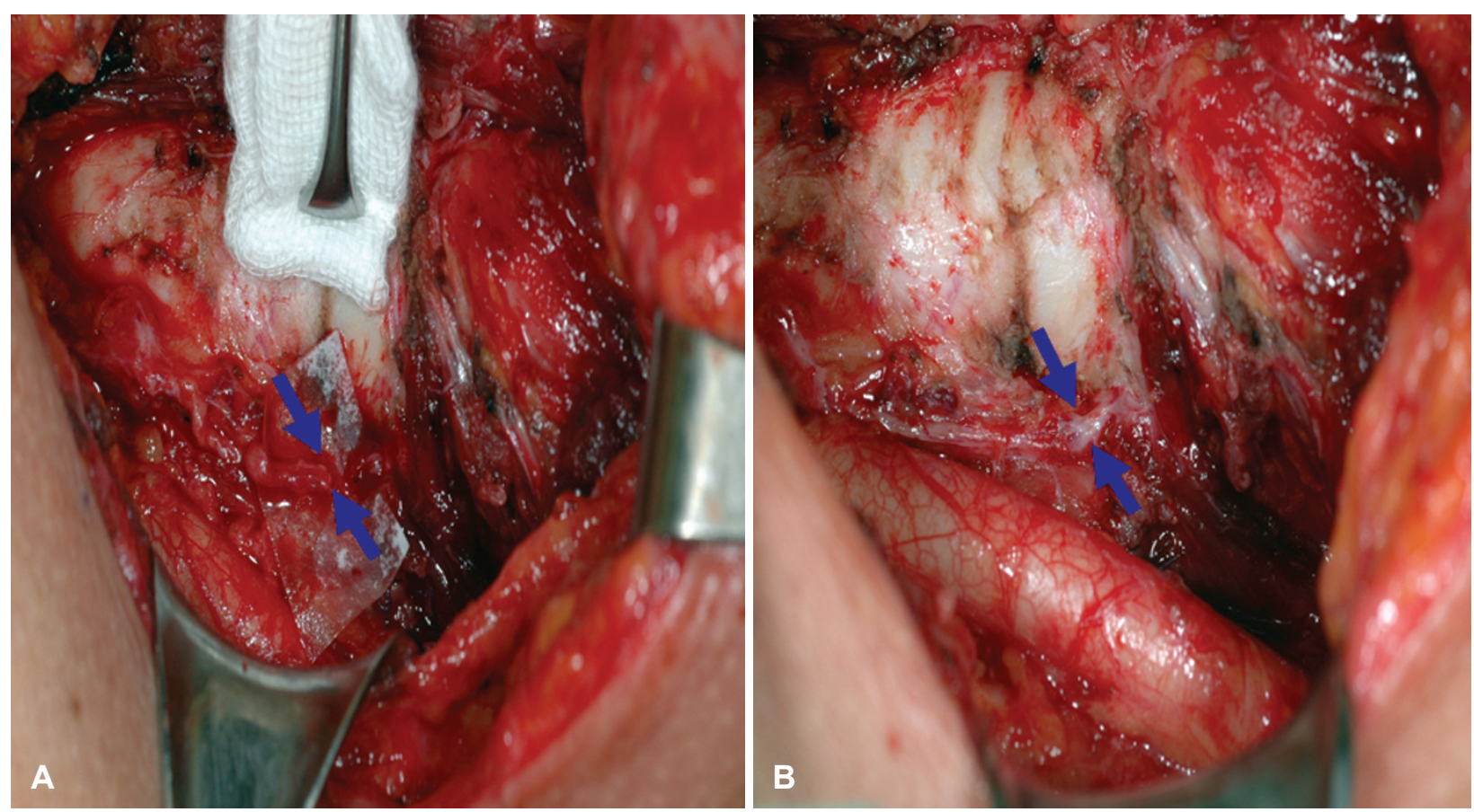

Fig. 4. Procedures of direct reinnervation. 4-5 times interrupted epineural suture was performed with 9-0 nylon (A) and after reinnervation (arrows) (B). 
training)을 시행해 볼 수 있으나, 효과적이지 않아서 장기적으 로는 내전형 양측 성대마비보다 치료가 어려운 것이 현실이다.

임상에 적용 가능한 내전형 양측 성대마비의 치료방법으로 는 아래와 같다.

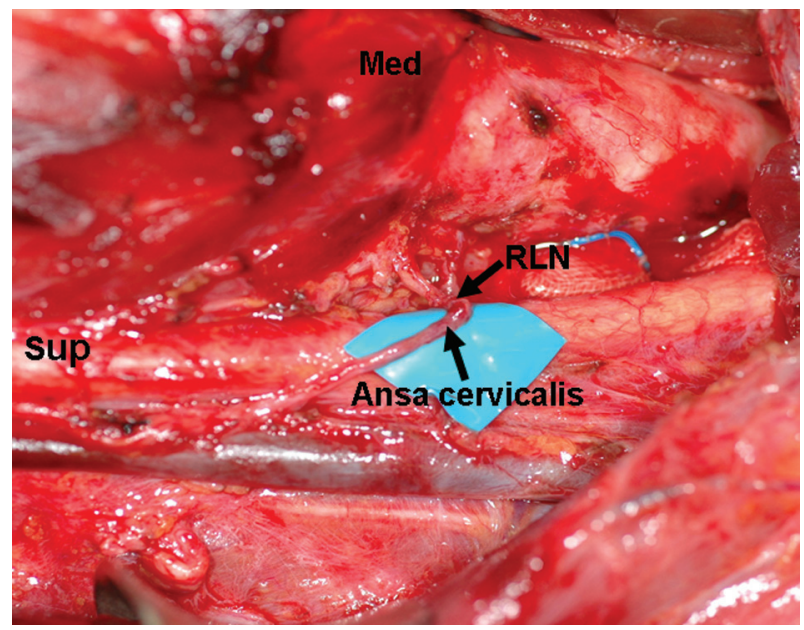

Fig. 5. In the ansa cervicalis to RLN reinnervation procedure, the branches of the ansa cervicalis were identified and mobilized. The ansa cervicalis was anastomosed directly to the recurrent laryngeal nerve using interrupted 9-0 nylon epineural sutures. RLN: recurrent laryngeal nerve. Sup: superior direction, Med: medial direction.
1) 주기적인 관찰(wait \& see)

2) 기관절개술 혹은 기관개창술(tracheotomy vs. tracheal fenestration)

3) 성대후방절개술 \pm 피열연골 부분 절제술(posterior cordotomy \pm medial partial arytenoidectomy)

4) 성대외전술(vocal fold lateralization)

5) 피열연골외전술(arytenoid abduction)

\section{성대후방절개술士피열연골 부분 절제술(Posterior} cordotomy \pm medial partial arytenoidectomy)

과거에 국내에서는 기관절개술과 같이 간단하고, 안전한 술 식이 선호되었으나, 현재는 성대후방절개술(posterior cordotomy) 혹은 성대후방절개술과 피열연골 부분 절제술(posterior cordotomy with medial partial arytenoidectomy)이 가장 많 이 시술되고 있다. 이의 기본 원리는 성대의 앞쪽 $2 / 3(\mathrm{membra}-$ nous vocal fold)는 주로 발성(phonation)에 관여하고, 뒤쪽 $1 / 3$ 은 호흡(respiration)에 관여하는 점을 근거로 성대후방과 피열연골의 일부를 절제하여 기도(airway)를 확보하는 방법 이다. 실제로는 기도 확보를 위하여 음성의 희생을 동반하는 술식으로 보는 것이 더 정확하다고 할 수 있다.

Fig. 6. Fiberscopic images of adductor type bilateral vocal fold paralysis (A) and abductor type bilateral vocal fold paralysis patients $(B)$.
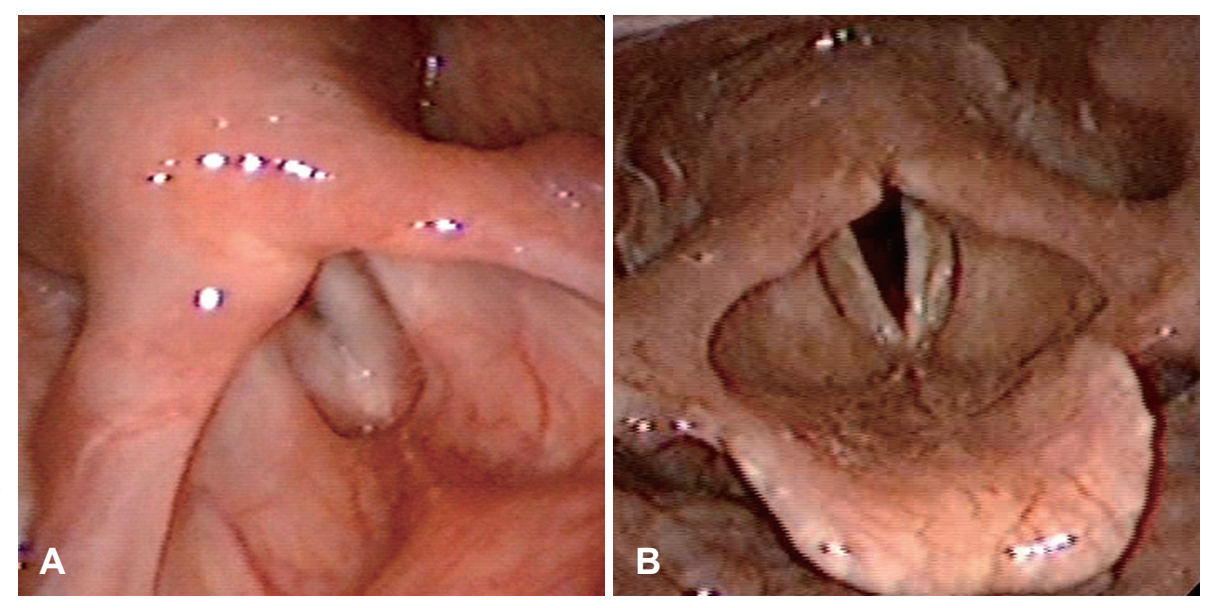

Fig. 7. Intraoperative images of right posterior cordotomy with medial partial arytenoidectomy $(A)$. And fiberscopic images demonstrated patent airway at postoperative 1 year (B).
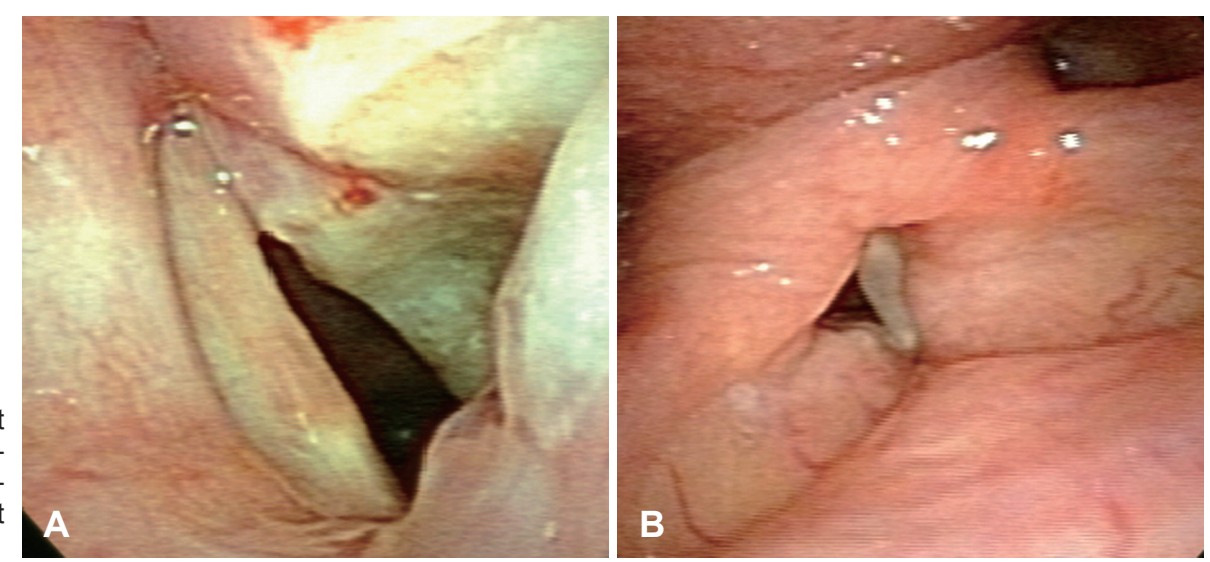
술식은 일반적으로 기도삽관이 된 상태에서 시술을 시행하 고, 기도삽관의 화재예방을 위하여 레이저튜브(laser shield tube)를 사용하는 것이 원칙이다. 저자의 경우 무호흡 수술기 법(apnea technique)하에서 성대후방절개술과 피열연골 부분 절제술을 함께하는 방법을 선호하며, 이는 성대후방절개술 만으로는 수술 후 재협착되는 일이 흔하기 때문이다. 유의사 항으로는 성대후방절개술 시 갑상연골의 내측에 도달할 때 까지 충분히 깊게 후방성대를 절개하는 것과, 피열연골 부분 절제술 시에는 수술 후 육아종 방지를 위하여 과도한 피열연 골이 노출되지 않도록 하는 것이 중요하다(Fig. 7).

저자의 경우 수술 부위의 육아종 방지를 위하여 약 2 3개월 정도의 양전자펌프차단제(proton pump inhibitor)를 사용하는 것을 추천하고 있다.

\section{양측성 성대마비의 새로운 시도}

\section{후두박동기(Laryngeal pacing)}

현재까지의 치료방법으로는 양측으로 마비된 성대를 움직 일 수 있는 방법은 없다. 심장박동기(cardiac paing)와 같은 원리로 손상된 근육을 전기자극으로 기계적으로 수축시켜 움직이는 것인데, 후두박동기의 경우 후윤상피열근(posterior cricoarytenoid muscle, PCA)을 전기적으로 자극해서 성대 를 열리게 하여, 호흡이 가능하게 한다.

2015년 AH Mueller, C Phototschnig, R Hagen 등은 양측 성 성대마비 환자에서 MedEL사(Innsbruck, Austria)의 후두 박동기(laryngeal pacing)를 이용한 무작위 임상연구(randomized controlled trials)를 통하여, 환자의 호흡 및 음성 능 력의 유의한 호전을 보고하였다. ${ }^{17)}$ 아직 치료방법이 각 교수들 의 선호도에 따라 Gera법, Insbruck법, Wurzbruck법 등 여러 방법이 시행되고 있고, 환자의 호흡 운동과 무관하게 일정한
빈도로 성대를 열리게 하는 수준이나, 조만간 임상에 적용될 가능성이 높으며, 이는 양측성 성대마비 환자에게 있어서 획 기적인 치료가 될 것으로 기대가 된다.

선택적 후두신경재지배술(Selective laryngeal reinnervation procedure)

최근 프랑스 Rouen 대학의 Jean-Paul Marie 교수는 다년 간의 개 실험 후, 선택적 후두신경재지배술(bilateral selective laryngeal reinnervation)을 임상 적용하여, 환자의 성대운 동기능 및 호흡기능을 회복한 전향적 임상시험(prospective clinical trials) 결과를 발표하였다. 수술법으로는 횡격막(diaphragm)으로 내려가는 횡격막신경(phrenic nerve)의 뿌리(cervical plexus)와 후윤상피열근(PCA)으로 가는 반회후두신 경을 현미경하에서 접합하고(microanastomosis), 반대편 후 윤상피열근은 반대편 반회후두신경과 경부신경총(cervical plexus)을 연결(interpositional graft)하는 수술법을 사용하 였다. ${ }^{18)} 1$ 년 이상의 추적관찰 결과 대부분의 환자에서 발관 이 가능하였고, 호흡 및 성대운동기능의 호전을 발표하였다. 이론적으로 이상적인 술식(ideal procedure)이나 양측 반회 후두신경, 횡격막신경(phrenic nerve), 경부신경총(cervical plexus)을 확인해야 하고, 광범위한 미세접합(microanastomosis) 및 이를 위한 넓은 경부 절개, 7 8시간의 긴 수술시간 등의 문제로 광범위하게 파급되기는 어려울 것으로 사료된다.

보툴리눔 독소 주입술(Botulinum toxin injection for bilateral vocal fold paralysis)

갑상선 수술 후 발생하는 대부분의 양측성 성대마비는 영 구적 양측 성대마비보다는 일시적 양측 성대마비가 많다. 이 경우 3 6개월 후 환자는 반회후두신경 기능을 회복할 수 있 으나, 내전형 양측 성대마비(adductor type) 환자의 경우 기도
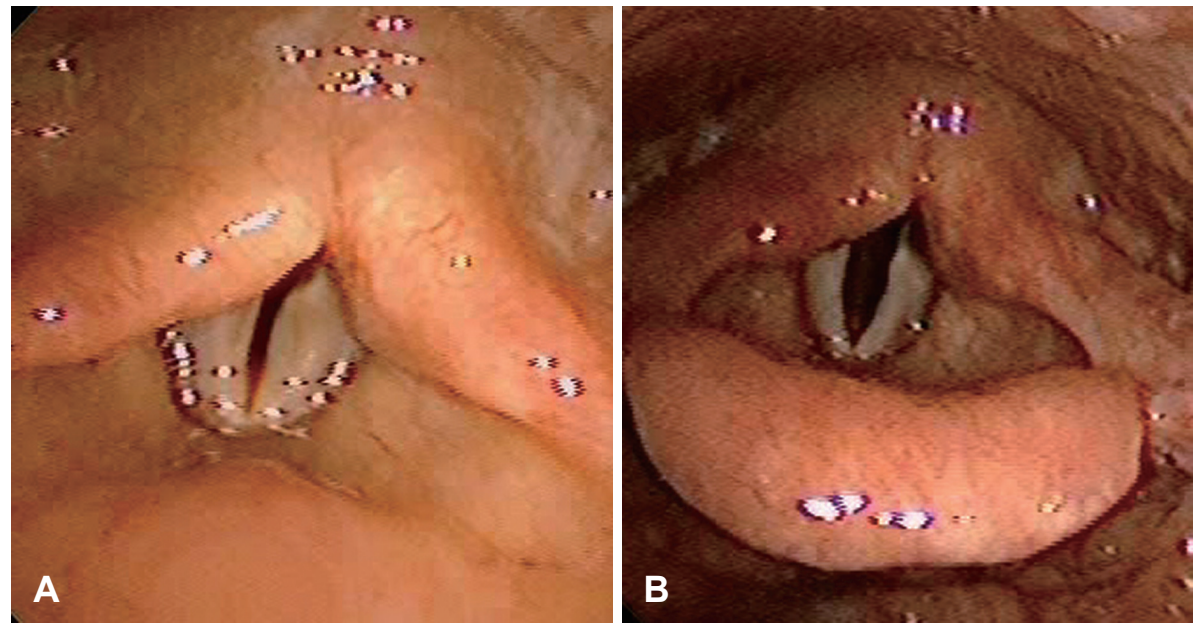

Fig. 8. Fiberscopic imaages of temporary bilateral vocal fold paralysis patients, before botulinum toxin injection $(A)$ and after 1 month botulinum toxin injection (B). 
확보를 목적으로 기관절개술(tracheotomy) 혹은 후 성대절개 술(posterior cordotomy)을 시술할 수밖에 없는 것이 현실이 다. 최근에는 이에 대한 대안으로 성대를 내측으로 닫히게 하 는 갑상피열근(thyroarytenoid muscle, TM)에 보툴리눔 독 소를 주사하는 방법이 시도되고 있다. ${ }^{19,20)}$ 이는 보툴리눔 독 소에 의해서 피열연골의 외측 회전(outward rotation of arytenoid cartilage), 성대 근육량의 감소, 성대 협동운동(synkinesis)의 감소에 의하여 성대 간격(glottal gap)을 확보하는 원리이다. 이는 생리적 신경차단(neuropraxia)에 의한 일시적 양측 성대마비의 경우 성대 근육을 마비시키는 보툴리눔 독 소를 양측 갑상피열근(TM)에 주입하여 기도를 확보한 뒤, 성 대기능의 회복을 기다리면서 비가역적인 기관절개술 혹은 성 대절개술을 피하는 원리이다. 단점으로는 반복적으로 3 6개 월 간격으로 보툴리눔 독소 주사가 필요하고, 기존 치료에 비
해 효과적인 우위는 아직까지 검증된 바가 없다. 저자의 경우 일시적 양측 성대마비 환자에서 반회후두신경 기능회복을 기다리는 동안 기도확보 목적으로 약 $2.5 \mathrm{U}$ 의 보툴리눔 독소 를 양측 갑상피열근에 주사하는 방법을 사용하고 있다(Fig. 8).

\section{갑상선 수술 후 성대마비 환자에서의 저자 치료 프로토콜}

갑상선 수술 후 성대마비 환자의 치료방법에 대해서는 여 러 가지 논란 점이 있으나, 저자는 현재 아래와 같은 프로토 콜에 따라 갑상선 수술 후 성대마비 환자를 치료하고 있다 (Figs. 9 and 10).

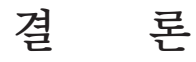

갑상선 수술은 수술 후 5년 생존율이 99\%에 달할 정도로
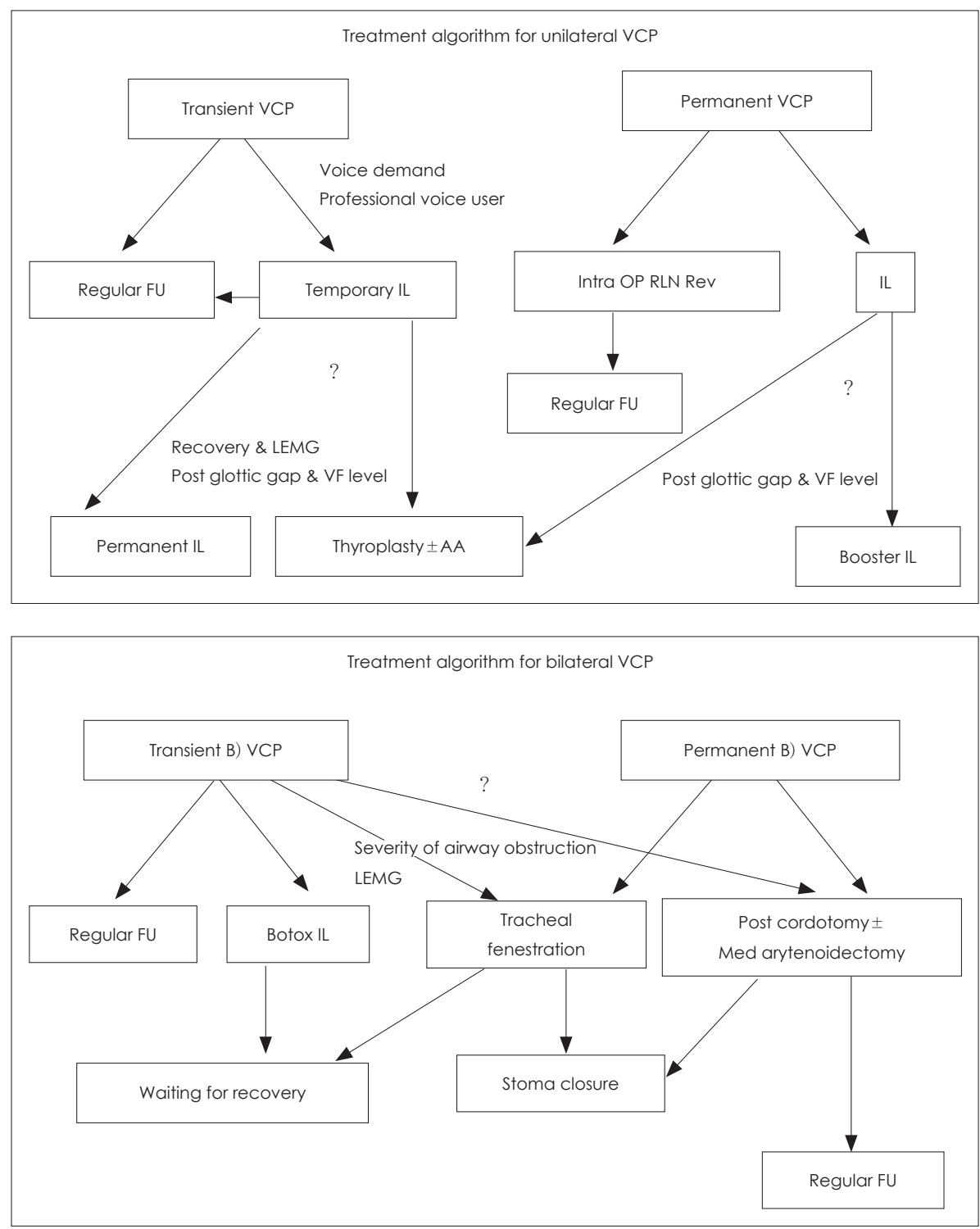

Fig. 9. Author's treatment algorithm for thyroidectomy related unilateral vocal fold paralysis patients. Regular FU: regular endoscopic follow up, VCP: vocal cord paralysis, IL: injection laryngoplasty, LEMG: laryngeal electromyography, AA: arytenoid adduction, RLN Rev: recurrent laryngeal reinnervation, intra OP: intraoperative, VF: vocal fold.
Fig. 10. Author's treatment algorithm for thyroidectomy related bilateral vocal fold paralysis patients. Regular FU: regular endoscopic follow up, B) VCP: bilateral vocal cord paralysis, Botox injection: botulinum toxin injection to thyroarytenoid muscle, LEMG: laryngeal electromyography. 
예후가 좋은 암으로, 수술 목적이 암 생존율뿐만 아니라, 수 술 후 삶의 질 유지에 목적을 두어야 한다. 한국 의료계 여건 상 일반외과와 갑상선-두경부 외과의사가 갑상선 수술의 주 도권을 가지고 경쟁하고 있는 상황에서 이비인후과에서 독점 적 경쟁력을 가지고 있는 갑상선 수술 후 음성장애 및 성대 마비에 적절한 치료를 제공함으로써, 환자의 삶의 질 향상과 갑상선 수술의 경쟁력 제고에 도움이 될 것으로 사료된다.

\section{REFERENCES}

1) Sinagra DL, Montesinos MR, Tacchi VA, Moreno JC, Falco JE, Mezzadri NA, et al. Voice changes after thyroidectomy without recurrent laryngeal nerve injury. J Am Coll Surg 2004;199(4):556-60.

2) Park KN, Mok JO, Chung CH, Lee SW. Does postthyroidectomy syndrome really exist following thyroidectomy? Prospective comparative analysis of open vs. endoscopic thyroidectomy. Clin Exp Otorhinolaryngol 2015;8(1):76-80.

3) Hong KH, Kim YK. Phonatory characteristics of patients undergoing thyroidectomy without laryngeal nerve injury. Otolaryngol Head Neck Surg 1997;117(4):399-404.

4) Hong KH, Ye M, Kim YM, Kevorkian KF, Berke GS. The role of strap muscles in phonation--in vivo canine laryngeal model. J Voice 1997;11(1):23-32.

5) Takamura $Y$, Miyauchi A, Tomoda C, Uruno T, Ito $Y$, Miya A, et al. Stretching exercises to reduce symptoms of postoperative neck discomfort after thyroid surgery: prospective randomized study. World J Surg 2005;29(6):775-9.

6) Rosen CA. Phonosurgical vocal fold injection: procedures and materials. Otolaryngol Clin North Am 2000;33(5):1087-96.

7) Isshiki $\mathrm{N}$, Okamura $\mathrm{H}$, Ishikawa $\mathrm{T}$. Thyroplasty type I (lateral compression) for dysphonia due to vocal cord paralysis or atrophy. Acta Otolaryngol 1975;80(5-6):465-73.

8) McCulloch TM, Hoffman HT, Andrews BT, Karnell MP. Arytenoid adduction combined with Gore-Tex medialization thyroplasty.
Laryngoscope 2000;110(8):1306-11.

9) Lee SW, Kim JW, Chung CH, Mok JO, Shim SS, Koh YW, et al. Utility of injection laryngoplasty in the management of postthyroidectomy vocal cord paralysis. Thyroid 2010;20(5):513-7.

10) Min JY, Hong SD, Kim K, Son YI. Long-term results of Artecoll injection laryngoplasty for patients with unilateral vocal fold motion impairment: safety and clinical efficacy. Arch Otolaryngol Head Neck Surg 2008;134(5):490-6.

11) Park KN, Cho SH, Lee SW. Nationwide multicenter survey for current status of endoscopic thyroidectomy in Korea. Clin Exp Otorhinolaryngol 2015;8(2):149-54.

12) Moon IH, Park KN, Kim HK, Lee S. Utility and safety of commercially available injection laryngoplasty materials in a rabbit model. J Voice 2015;29(1):125-8.

13) Paniello RC, Edgar JD, Kallogjeri D, Piccirillo JF. Medialization versus reinnervation for unilateral vocal fold paralysis: a multicenter randomized clinical trial. Laryngoscope 2011;121(10):2172-9.

14) Aynehchi BB, McCoul ED, Sundaram K. Systematic review of laryngeal reinnervation techniques. Otolaryngol Head Neck Surg 2010;143(6):749-59.

15) Lee SW, Park KN, Oh SK, Jung CH, Mok JO, Kim CH. Long-term efficacy of primary intraoperative recurrent laryngeal nerve reinnervation in the management of thyroidectomy-related unilateral vocal fold paralysis. Acta Otolaryngol 2014;134(11):1179-84.

16) Lo CY, Kwok KF, Yuen PW. A prospective evaluation of recurrent laryngeal nerve paralysis during thyroidectomy. Arch Surg 2000;135 (2):204-7.

17) Mueller AH. Laryngeal pacing for bilateral vocal fold immobility. Curr Opin Otolaryngol Head Neck Surg 2011;19(6):439-43.

18) Marina MB, Marie JP, Birchall MA. Laryngeal reinnervation for bilateral vocal fold paralysis. Curr Opin Otolaryngol Head Neck Surg 2011;19(6):434-8.

19) Andrade Filho PA, Rosen CA. Bilateral vocal fold paralysis: an unusual treatment with botulinum toxin. J Voice 2004;18(2):254-5.

20) Ekbom DC, Garrett CG, Yung KC, Johnson FL, Billante CR, Zealear $\mathrm{DL}$, et al. Botulinum toxin injections for new onset bilateral vocal fold motion impairment in adults. Laryngoscope 2010;120(4):758-63.

\section{정답 및 해설}

답 (1) Palatal island flap, (2) Greater palatine artery

해 설 Reference: 갑상선-두경부외과학. 대한갑상선두경부외과학회편. 서울: 범문에듀케이션;2014. p.705.

Palatal island flap은 수술시야 내에서 혹은 가까이에서 필요한 조직을 얻을 수 있는 장점이 있는데, 특히 구개궁, 구치후 삼각(retromolar trigone), 편도와, 연구개 그리고 구강저의 후방 $1 / 3$ 부위 등에 생긴 중등도 이하 크기의 결손을 재건시에 사용되며 주된 혈액 공급혈관은 greater palatine artery이다. 